\title{
Antileukemic Efficacy of Monomeric Manganese-Based Metal Complex on KG-1A and K562 Cell Lines
}

\author{
Sandeep Kumar Dash, ${ }^{1}$ Sourav Chattopadhyay, ${ }^{1}$ Totan Ghosh, ${ }^{2}$ Satyajit Tripathy, \\ Sabyasachi Das, ${ }^{1}$ Debasis Das, ${ }^{2}$ and Somenath Roy ${ }^{1}$ \\ ${ }^{1}$ Immunology and Microbiology Laboratory, Department of Human Physiology with Community Health, \\ Vidyasagar University, Midnapore, West Bengal 721 102, India \\ ${ }^{2}$ Department of Chemistry, University of Calcutta, 92 A. P. C. Road, Kolkata 700 009, India
}

Correspondence should be addressed to Somenath Roy; sroy.vu@hotmail.com

Received 17 July 2013; Accepted 17 August 2013

Academic Editors: M. B. Gariboldi, Z. S. Guo, and R. Sanchez-Prieto

Copyright (C) 2013 Sandeep Kumar Dash et al. This is an open access article distributed under the Creative Commons Attribution License, which permits unrestricted use, distribution, and reproduction in any medium, provided the original work is properly cited.

\begin{abstract}
Transitional metals and metal compounds have been used in versatile platforms for biomedical applications and therapeutic intervention. Severe side effects of anticancer drugs produce an urgent urge to develop new classes of anticancer agents with great potency as well as selectivity. In this background, recent studies demonstrate that monomeric manganese (MnII) thiocyanate complex (MMTC) holds great promise to exert effective antileukemic effects. MMTC was developed by a simple chemical reaction and characterized by elemental analyses, thermal analyses, and Fourier transform infrared (FTIR) spectroscopy. Anti-leukemic efficacy of the developed MMTC was estimated in KG-1A (AML) and K562 (CML) cell lines. Cell viability study, drug uptake assay, cellular redox balance (GSH and GSSG level), nitric oxide (NO) release level, reactive oxygen species (ROS) formation, alteration of mitochondrial membrane potential (MMP), and DNA fragmentation revealed that MMTC was able to produce significant antiproliferative effects on both cell lines at $25 \mu \mathrm{g} \mathrm{mL}^{-1}$ without showing any toxicological impact on normal lymphocytes. These findings will enlighten the biomedical application of manganese-based metal complexes as anti-leukemic agents.
\end{abstract}

\section{Introduction}

Leukemia is a type of cancer of the blood or bone marrow, characterized by an abnormal increase of immature white blood cells called "blasts" [1]. Acute myelogenous leukemia (AML) is a fast growing fatal form of leukemia which produces immature white blood cells, begins in bone marrow cells, and spreads into the blood system. Chronic myelogenous leukemia (CML) is an uncommon type of leukemia, making up about $15 \%$ of all the cases of leukemia among adults, results from a somatic mutation in a pluripotential lymphohematopoietic cell, and thereby produces large number of white blood cells [2]. The modern research regarding the development of the metal-based anticancer drugs began with the discovery of the platinum (II) complex cisplatin by Rosenberg in the 1960s [3]. Metal complex or coordination compound is a structure consisting of a central metal atom that remains surrounded by molecules or anions. Transition metal complexes have an esteemed role in antitumor therapy and open a new area of research in the field of medicinal chemistry [4]. Nowadays, metal ion complexes had quickly turned out to be an interesting and attractive compounds in the development of anticancer drugs due to their unique chemical reactivity [5]. This phenomenon has started the development of metal-based drugs with promising pharmacological application and may offer unique therapeutic opportunities [6]. The use of metal complexes as therapeutic agents has become more pronounced due to their diverse mode of action not only in cancer therapy but also in that they can be used as anti-inflammatory, anti-infective, and antidiabetic compounds [7]. Many cytotoxic metal complexes target DNA as they exert a great role in replication and cell viability. Another important characteristic of metal complexes is their potentiality to alter the cellular redox homeostasis by switching between several oxidation states [8]. Cancer cells are different from healthy cells due to their unique redox 
balances and the generation of high level of reactive oxygen species (ROS). Consequently, metal complexes interfere with the cellular redox homeostasis, stimulate generation of ROS, and interact with DNA strands and thereby produce antiproliferative activity against cancer cells. In a biological system, manganese (transitional metal) plays a great role as an everincreasing number of biomolecules were found to contain manganese, including manganese-containing superoxide dismutase (Mn-SOD), catalase, Mn-ribonucleotide reductase, and Mn-peroxidase. Mn-SOD actively eliminates harmful free radicals from cellular systems [9]. So, Mn containing complexes may be a valuable agent in antileukemic therapy. To the best of our knowledge, still now no work has been carried out regarding the anti-leukemic potential of monomeric manganese thiocyanate complex (MMTC). Considering this background, the present work has been carried out to develop the MMTC and to evaluate its antileukemic activity in human acute myelogenous leukemia (AML) and human chronic myelogenous leukemia (CML) cell lines. Doxorubicin (DOX) has been included in this study as a positive control drug.

\section{Materials and Methods}

2.1. Culture Media and Chemicals. Manganese (II) perchlorate hexahydrate and 2-benzoylpyridine were purchased from Aldrich Chemical Company and used as received. Crystal violet solution, Histopaque 1077, and Rhodamine B were procured from Sigma. RPMI 1640, penicillin, streptomycin, and doxorubicin were procured from Sigma (St. Louis, MO, USA). Fetal bovine serum (FBS) was purchased from Gibco/Invitrogen. Sodium chloride (Nacl), sodium carbonate $\left(\mathrm{Na}_{2} \mathrm{CO}_{3}\right)$, sucrose, Hanks balanced salt solution (HBSS), HEPES-Na+ buffer, and 3-[4,5-dimethylthiazol-2-yl]-2,5diphenyltetrazolium bromide (MTT) were purchased from Himedia, India. Tris- $\mathrm{HCl}$, Tris buffer, $\mathrm{KH}_{2} \mathrm{PO}_{4}, \mathrm{~K}_{2} \mathrm{HPO}_{4}$, $\mathrm{HCl}$, formaldehyde, alcohol, Triton X-100, sodium dodecyl sulphate (SDS), phenol, chloroform, isoamyl alcohol, ethidium bromide (EtBr), 2-vinylpyridine and other chemicals were procured from Merck Ltd., SRL Pvt. Ltd., Mumbai, India. Commercially available dimethyl sulfoxide (DMSO) was procured from Hi-media, India, and was purified by vacuum distillation over $\mathrm{KOH}$. All other chemicals were from Merck Ltd., SRL Pvt. Ltd., Mumbai, India, and were of the highest purity grade available. Solvents were dried according to the standard procedure and distilled prior to use [10].

2.2. Preparation of Mononuclear Complex $\left[\mathrm{Mn}(\mathrm{Phpyk})_{2}\right.$ $\left.(\mathrm{SCN})_{2}\right]$. Mononuclear complex $\left[\mathrm{Mn}(\mathrm{Phpyk})_{2}(\mathrm{SCN})_{2}\right]$ (MMTC) was prepared according to our previously reported method [11]. In brief, a methanolic solution $(5 \mathrm{~mL})$ of 2-benzoylpyridine (Phpyk) $(0.366 \mathrm{~g} ; 2 \mathrm{mmol}$ ) was added dropwise with constant stirring to $10 \mathrm{~mL}$ methanolic solution of manganese (II) perchlorate hexahydrate ( $1 \mathrm{mmol} ; 0.362 \mathrm{~g}$ ). The stirring was continued for further $1 \mathrm{~h}$, and then, an aqueous solution $(5 \mathrm{~mL})$ of sodium thiocyanate $(0.162 \mathrm{~g}$; $2 \mathrm{mmol}$ ) was added dropwise. After $2 \mathrm{~h}$ stirring, the resulting mixture was filtered and the filtrate was kept in a $\mathrm{CaCl}_{2}$ desiccator.

2.3. Physical Measurements. Elemental analyses (carbon, hydrogen, and nitrogen) were performed using a PerkinElmer 240C elemental analyzer. Thermal analyses (TGA) were carried out on a TGA/SDTA851e Mettler-Toledo thermal analyzer. For the TGA test, the sample was heated from room temperature to $700^{\circ} \mathrm{C}$ under flowing nitrogen atmosphere (flow rate: $40 \mathrm{~cm}^{3} \mathrm{~min}^{-1}$ ) at a heating rate of $10^{\circ} \mathrm{C} \mathrm{min}^{-1}$ in a platinum crucible. To determine the structural features of the samples, Fourier transform infrared (FTIR) spectroscopy was carried out at $25^{\circ} \mathrm{C}$ using a PerkinElmer Spectrum RXIFT-IR System FT-IR spectrometer with 64 scans for wave numbers ranging from 400 to $4000 \mathrm{~cm}^{-1}$ and resolution $4 \mathrm{~cm}^{-1}$. The $\mathrm{KBr}$ pellet method was used to prepare the samples [11].

2.4. Cell Lines Culture and Maintenance. KG-1A and K562 cell lines were obtained from NCCS, Pune, India. All cell lines were cultivated and maintained in RPMI-1640 complete media supplemented with $10 \%$ heat inactivated fetal bovine serum (FBS), $2 \mathrm{mM}$ glutamine, $100 \mathrm{U} \mathrm{mL}^{-1}$ penicillin, $100 \mu \mathrm{g} \mathrm{mL}^{-1}$ streptomycin, and $4 \mathrm{mM} \mathrm{L}$-glutamine under $5 \%$ $\mathrm{CO}_{2}$ and $95 \%$ humidified atmosphere at $37^{\circ} \mathrm{C}$ in a $\mathrm{CO}_{2}$ incubator. Cells were cultured and maintained in logarithmic growth phase until the number of cells reaches $1.0 \times 10^{6}$ cells $\mathrm{mL}^{-1}$.

2.5. Selection of Human Subjects for the Collection of Lymphocytes. Six healthy subjects were chosen to collect the blood sample for separation of lymphocytes. All subjects enrolled in this study were asymptomatic, and none of them had abnormality on physical examinations and routine laboratory tests. The subjects were from same geographical area and same economic status, nonsmokers and nonalcoholic, and having the same food habit. These subjects received no medication, including vitamin $\mathrm{E}$ and vitamin $\mathrm{C}$. All subjects gave informed consent. The selection excluded not only individuals with acute infections or chronic diseases, but also healthy individuals undergoing supplementation with antioxidants. The study protocol was in accordance with the declaration of Helsinki, and was approved by the institutional ethical committee of Vidyasagar University [12].

2.6. Isolation of Peripheral Blood Lymphocytes. Blood samples were collected from these six healthy human volunteers by venipuncture in $5 \mathrm{~mL}$ heparin coated vacutainers satisfying the method of Hudson and Hay [13]. Five milliliters of blood was diluted (1:1) with phosphate buffered saline (PBS) and layered onto Histopaque 1077 (Sigma) by using a Pasteur pipette and centrifuged at $400 \times \mathrm{g}(1500 \mathrm{rpm})$ for $40 \mathrm{~min}$ at room temperature. The upper monolayer of buffy coat, that is, lymphocytes, was transferred using a clean Pasteur pipette to a clean centrifuge tube and washed three times in a balanced salt solution. The lymphocytes were resuspended in RPMI complete media supplemented with 10\% FBS and incubated 
for a day at $37^{\circ} \mathrm{C}$ in a $95 \%$ air $/ 5 \% \mathrm{CO}_{2}$ atmosphere in a $\mathrm{CO}_{2}$ incubator.

2.7. Drug Preparation. A $10 \mathrm{mg} / \mathrm{mL}$ stock of MMTC was prepared by dissolving $10 \mathrm{mg}$ of MMTC in DMSO. It was then serially diluted with RPMI media to prepare working concentrations. The amount of DMSO for each concentration, never exceeded $>0.75 \%$.

2.8. Experimental Design. Each type of cells was divided into 9 groups. Each group contained six (6) petri dishes $(2 \times$ $10^{5}$ cells in each). The cells of each petri dish of control and experimental groups were maintained in RPMI 1640 media supplemented with $10 \% \mathrm{FBS}, 50 \mu \mathrm{g} \mathrm{m}^{-1}$ gentamicin, $50 \mu \mathrm{g} \mathrm{mL}^{-1}$ penicillin, and $50 \mu \mathrm{g} \mathrm{mL}^{-1}$ streptomycin at $37^{\circ} \mathrm{C}$ in a $95 \%$ air $/ 5 \% \mathrm{CO}_{2}$ atmosphere in a $\mathrm{CO}_{2}$ incubator. The following groups were considered for the experiment and cultured for $24 \mathrm{~h}$ :

Group I: control, that is, cells + culture media;

Group II: cells $+1 \mu \mathrm{g} \mathrm{mL}^{-1}$ doxorubicin in culture media;

Group III: cells $+1 \mu \mathrm{g} \mathrm{mL}^{-1}$ MMTC in culture media;

Group IV: cells $+10 \mu \mathrm{g} \mathrm{mL}^{-1}$ doxorubicin in culture media;

Group V: cells $+10 \mu \mathrm{g} \mathrm{mL}^{-1}$ MMTC in culture media;

Group VI: cells $+25 \mu \mathrm{g} \mathrm{m}^{-1}$ doxorubicin in culture media;

Group VII: cells $+25 \mu \mathrm{g} \mathrm{mL}^{-1}$ MMTC in culture media;

Group VIII: cells $+50 \mu \mathrm{g} \mathrm{mL}^{-1}$ doxorubicin in culture media;

Group IX: cells $+50 \mu \mathrm{g} \mathrm{mL}^{-1}$ MMTC in culture media.

After the treatment schedule, the cells were collected from the petri dishes separately and centrifuged at 2,200 RPM for $10 \mathrm{~min}$ at $4^{\circ} \mathrm{C}$ to separate cells and sups [12]. The cells were washed twice with $50 \mathrm{mM}$ PBS, $\mathrm{pH}$ 7.4. A required amount of cells was lysed using hypotonic lysis buffer (10 mM TRIS, $1 \mathrm{mM}$ EDTA, and Triton X-100, $\mathrm{pH} 8.0$ ) for $45 \mathrm{~min}$ at $37^{\circ} \mathrm{C}$ and then processed for the biochemical estimation [14]. Intact cells were used for determination of ROS, mitochondrial membrane potential, and different microscopic observations.

2.9. In Vitro Cell Proliferation Assay. The cytotoxicity of MMTC was quantitatively estimated by nonradioactive, colorimetric assay systems using tetrazolium salt, 3[4,5-dimethylthiazol-2-yl]-2,5-diphenyltetrazolium bromide (MTT). Briefly, MTT was dissolved in phosphate-buffered saline at $5 \mathrm{mg} \mathrm{mL}^{-1}$ and filter sterilized to remove the small amount of insoluble residue present in some batches. The MTT solution was then added directly to all appropriate microtiter plate wells ( $10 \mu \mathrm{L}$ per $100 \mu \mathrm{L}$ medium) containing cells and complete growth medium, with or without the nanoparticle. The plate was then incubated for $4 \mathrm{~h}$ at $37^{\circ} \mathrm{C}$ to allow MTT to metabolize to formazan. Subsequently, the supernatant was aspirated, and $100 \mu \mathrm{L}$ of $\mathrm{HCl}$-isopropanol solution (1:1) was added to each culture plate and mixed thoroughly to dissolve the dark blue formazan crystals. The optical density (OD) was measured on ELISA reader (BioRad, Model 550, Tokyo, Japan) using test and reference wavelengths of 570 and $630 \mathrm{~nm}$, respectively [14]. The percentage of proliferation was calculated by using the following equation:

$$
\% \text { Proliferation }=\frac{[\mathrm{OD} \text { sample }- \text { OD control }]}{\text { OD control }} \times 100 .
$$

2.10. In Vitro Drug Uptake Assay. In vitro MMTC uptake assay was performed according to standard methods [15] with some modifications. Briefly, cells were plated at a density of $2.5 \times 10^{4}$ cells/Petridis $(35 \mathrm{~mm})$ containing $12 \mathrm{~mm}$ sterile cover slips for $24 \mathrm{~h}$. Rhodamine B tagged MMTC at $10 \mu \mathrm{g} / \mathrm{mL}$ concentration were incubated for $6 \mathrm{~h}$ at $37^{\circ} \mathrm{C}$ in a $95 \%$ air $/ 5 \%$ $\mathrm{CO}_{2}$ atmosphere in a $\mathrm{CO}_{2}$ incubator. After a defined time, the cover slips were removed; the cells were washed 2 times with PBS and immediately observed in green light under the fluorescence microscope (Nikon Eclipse LV100POL) for uptake assessment. Images were acquired at 50x optical zoom, and analysis was done using ImageJ software v.r. 1.43 (NIH).

2.11. Determination of Reduced Glutathione (GSH). Reduced glutathione estimation in cell lysate was performed by the method of Dey and Roy [16]. The required amount of the sample was mixed with $25 \%$ of TCA and centrifuged at $2,000 \times \mathrm{g}$ for $15 \mathrm{~min}$ to settle down the precipitated proteins. The supernatant was aspirated and diluted to $1 \mathrm{~mL}$ with $0.2 \mathrm{M}$ sodium phosphate buffer ( $\mathrm{pH} 8.0$ ). After that, $2 \mathrm{~mL}$ of $0.6 \mathrm{mM}$ DTNB was added. After 10 minutes, the optical density of the yellow-colored complex formed by the reaction of GSH and DTNB (Ellman's reagent) was measured at $405 \mathrm{~nm}$. A standard curve was obtained with standard reduced glutathione. The levels of GSH were expressed as $\mu$ g of GSH mg ${ }^{-1}$ protein.

2.12. Determination of Oxidized Glutathione (GSSG). The oxidized glutathione level was measured after the derivatization of GSH with 2-vinylpryidine according to the method of Dey and Roy [16]. In brief, with $0.5 \mathrm{~mL}$ sample, $2 \mu \mathrm{L}$ of 2-vinylpryidine was added and incubated for $1 \mathrm{~h}$ at $37^{\circ} \mathrm{C}$. Then, the mixture was deproteinized with $4 \%$ sulfosalicylic acid and centrifuged at $1,000 \times \mathrm{g}$ for $10 \mathrm{~min}$ to settle the precipitated proteins. The supernatant was aspirated, and GSSG level was estimated with the reaction of DTNB at $412 \mathrm{~nm}$ in spectrophotometer and calculated with standard GSSG curve. The levels of GSSG were expressed as $\mu \mathrm{g}$ of GSSG mg ${ }^{-1}$ protein. All measurements were repeated at least three times.

2.13. Nitric Oxide Release Assay. After treatment schedule, $100 \mu \mathrm{L}$ of Griess reagent (containing 1 part of $1 \%$ sulfanilamide in $5 \%$ phosphoric acid and 1 part of $0.1 \%$ of $\mathrm{N}-\mathrm{C}-$ 1 naphthyl ethylene diaminedihydrochloride) was added to $100 \mu \mathrm{L}$ of supernatant incubated at room temperature for 10 
minutes; readings were taken in a UV spectrophotometer at $550 \mathrm{~nm}$ and compared to a sodium nitrite standard curve (values ranging between 0.5 and $25 \mu \mathrm{M}$ ). The levels of NO were expressed as $\mu \mathrm{M} \mathrm{mg}^{-1}$ protein [16]. All measurements were done in triplicate.

2.14. Intracellular ROS Measurement. ROS measurement was performed using $\mathrm{H}_{2}$ DCFDA according to the method of Ling et al. [17]. In brief, 96-well plates were seeded with $2 \times 10^{4}$ cells per well and allowed to adhere overnight. In all, 2, 5, and $10 \mathrm{mM}$ safingol added for the indicated period. $\mathrm{H}_{2} \mathrm{O}_{2}$ was used as a positive control. Following the drug treatment, the media were removed and cells were loaded with $5 \mathrm{mM} \mathrm{H} \mathrm{H}_{2}$ DCFDA diluted in clear media for 30 mins at $37^{\circ} \mathrm{C}$ and washed three times using PBS (1X), and then, DCF fluorescence was determined at $485 \mathrm{~nm}$ excitation and $520 \mathrm{~nm}$ emission using a Hitachi F-7000 fluorescence spectrophotometer. DCF fluorescence was also observed by fluorescence microscopy. DCF-fluorescence intensity of untreated cells was set to 1.00. All measurements were done in triplicate.

2.15. Measurement of Mitochondrial Membrane Potential $(\Delta \Psi m)$. The alteration of mitochondrial membrane potential by spectrofluorometric method was done according to the previously reported method [18]. Briefly, both the control and experimental cells exposed to MMTC at $25 \mu \mathrm{g} \mathrm{mL}^{-1}$ for $18 \mathrm{hr}$, were washed and suspended in ice-cold PBS. Approximately $1 \times 10^{6}$ cells $\mathrm{mL}^{-1}$ number of cells were incubated with $10 \mathrm{mM} \mathrm{Rh} 123$ at $37^{\circ} \mathrm{C}$ for $30 \mathrm{~min}$ and then washed twice with PBS. The cellular fluorescence intensity of Rh 123 was monitored for 2 min using Hitachi F-7000 fluorescence spectrophotometer. The cellular mitochondrial membrane potential was expressed as a percentage of control cells at an excitation wavelength of $485 \mathrm{~nm}$ and an emission wavelength of $530 \mathrm{~nm}$. Both excitation and emission slit width were set to 5.0. All measurements were done in triplicate.

2.16. DNA Fragmentation Study by Agarose Gel Electrophoresis. DNA gel electrophoresis was performed as described in our previous lab report [19]. In brief, after the treatment schedule, the cells were resuspended in $270 \mu \mathrm{L}$ precooled lysis buffer (10 mM Tris- $\mathrm{Hcl}, 10 \mathrm{mM} \mathrm{NaCl}$, and $10 \mathrm{mM}$ EDTA, $\mathrm{pH}$ 7.4) with $30 \mu \mathrm{L}$ SDS (10\%). RNase A (final concentration $100 \mu \mathrm{g} \mathrm{mL}^{-1}$ ) was then added, and incubation was continued at $45^{\circ} \mathrm{C}$ for $45 \mathrm{~min}$. Subsequently, proteinase $\mathrm{K}$ (final concentration $100 \mu \mathrm{g} / \mathrm{mL}$ ) was added to the cell lysate, and incubation was continued at $50^{\circ} \mathrm{C}$ for overnight to complete digestion. DNA was isolated from the lysate using phenol/chloroform/isoamyl alcohol. Then, DNA was precipitated with one volume of $10 \mathrm{M}$ sterile ammonium acetate, and two volumes of absolute ethanol followed by centrifugation at $13000 \times \mathrm{g}$ for $10 \mathrm{~min}$ at $4^{\circ} \mathrm{C}$. The extracted DNA samples were washed with $70 \%$ ethanol and dissolved in $50 \mu \mathrm{L}$ TE buffer (10 mM Tris-Hcl, $1 \mathrm{mM}$ EDTA, pH 7.6). Gel loading buffer (10 mM EDTA, 0.25\% bromophenol blue, and 30\% glycerol) was then added to the DNA sample at 1:5 ratio and loaded onto a $1.2 \%$ agarose gel. The electrophoresis was carried out at
$50 \mathrm{~V}$ for $90 \mathrm{~min}$ in TBE buffer $(90 \mathrm{mM}$ Tris-Hcl, $2 \mathrm{mM}$ EDTA, and $90 \mathrm{mM}$ boric acid, $\mathrm{pH}$ 8.0). After electrophoresis, DNA was visualized by soaking the gel in TBE buffer containing $1.5 \mu \mathrm{g} \mathrm{mL}^{-1}$ ethidium bromide in UV light, and the picture was captured in Bio-Rad gel documentation system.

2.17. Statistical Analysis. All the parameters were repeated at least three times. The data were expressed as mean \pm SEM, $n=06$. Comparisons between the means of control and the treated group were made by one-way ANOVA test (using a statistical package, Origin 6.1, Northampton, MA, USA) with multiple comparison $t$ tests, $P<0.05$ as a limit of significance.

\section{Result and Discussion}

Leukemia is a life threatening hematological malignancy characterized by uncontrolled cell growth. Transition metals have an important role in biomedical application. Research has shown significant progress in the utilization of transition metal complexes as drugs to treat several human diseases like carcinomas, lymphomas, infection control, antiinflammatory, diabetes, and neurological disorders [4]. In the present, we successfully prepared mononuclear complex $\left[\mathrm{Mn}(\mathrm{Phpyk})_{2}(\mathrm{SCN})_{2}\right]$ by chemical reactions. The single crystals of MMTC suitable for X-ray data collection were obtained from the filtrate after a few days. Yield: 90. Anal. Calcd for $\mathrm{C}_{26} \mathrm{O}_{2} \mathrm{~N}_{4} \mathrm{~S}_{2} \mathrm{H}_{18} \mathrm{Mn}$ : C, 58.05; H, 3.35; N, 10.42 (\%). Found: C, 58.13; H, 3.28; N, 10.37 (\%). IR: $v(\mathrm{SCN})=2076 \mathrm{~cm}^{-1}$, $\nu(\mathrm{C}=\mathrm{O})=1625 \mathrm{~cm}^{-1}, \nu($ skeletal vibration $)=1579 \mathrm{~cm}^{-1}$.

\subsection{Crystallographic Data Collection and Refinement.} Diffraction data for all the structures reported were collected at room temperature on a Bruker Smart Apex diffractometer (Mo-K $\alpha$ radiation, $\lambda=0.71073 \AA$ ) equipped with a CCD. Cell refinement, indexing, and scaling of the data set were carried out using Bruker Smart Apex packages, and Bruker Saint Package [20]. All the structures were solved by direct methods and subsequent Fourier analyses [21] and refined by the full-matrix least-squares method based on $F^{2}$ with all observed reflections (Figure 1(a)).

3.2. Solid State Thermal Studies of the Complex. Solid state thermal analyses have been performed in order to (i) understand the thermal decomposition patterns of the complexes, (ii) to verify the molecular composition of the complexes, and (iii) to synthesize the thermally stable end products. Critical analyses suggest that MMTC yields corresponding metal sulfides as the end products. The thermogram as well as the calculated and experimental weight losses, temperature range of decomposition are reported here (Figure 1(b) and Table 1).

3.3. IR Spectral Study. The MMTC exhibits very strong sharp single band in the range of $2094 \mathrm{~cm}^{-1}$ which corresponds to the stretching frequency of SCN moiety. The complex exhibits IR stretching frequencies corresponding to the carbonyl 


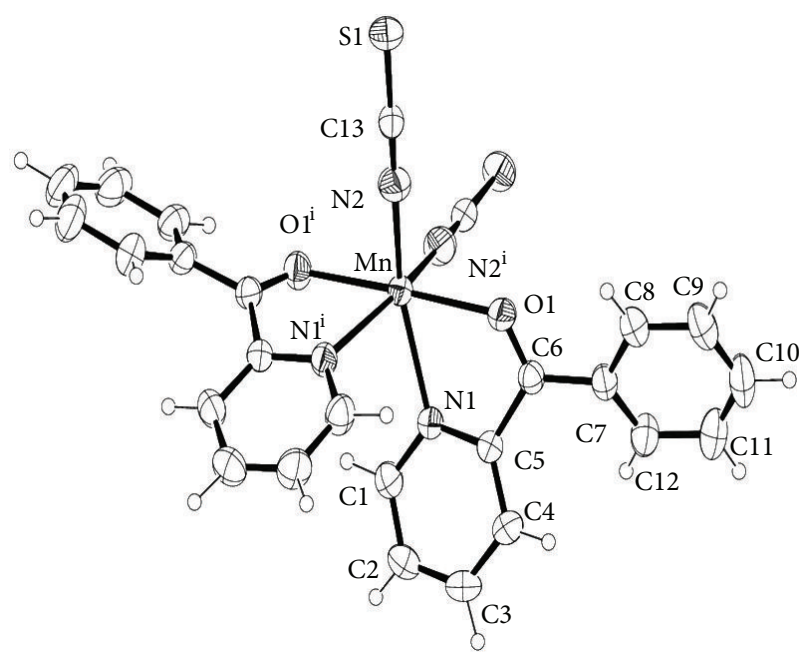

(a)

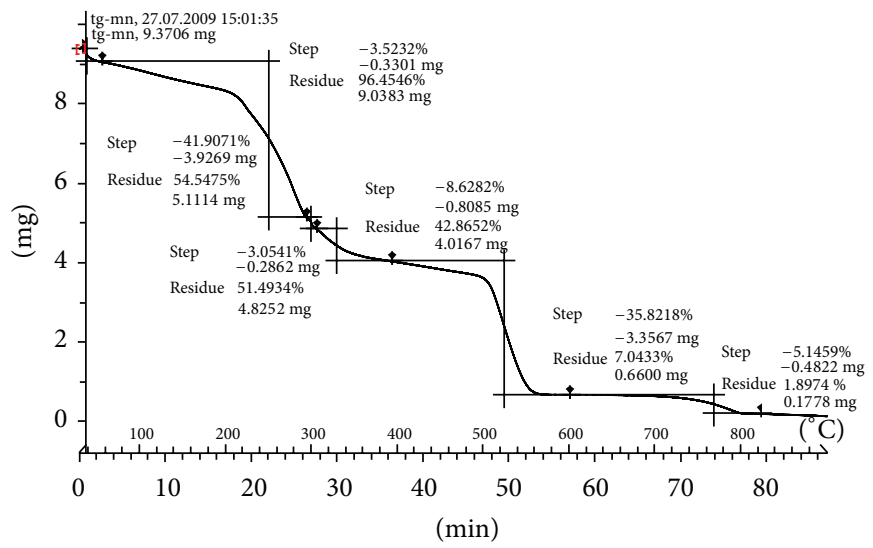

(b)

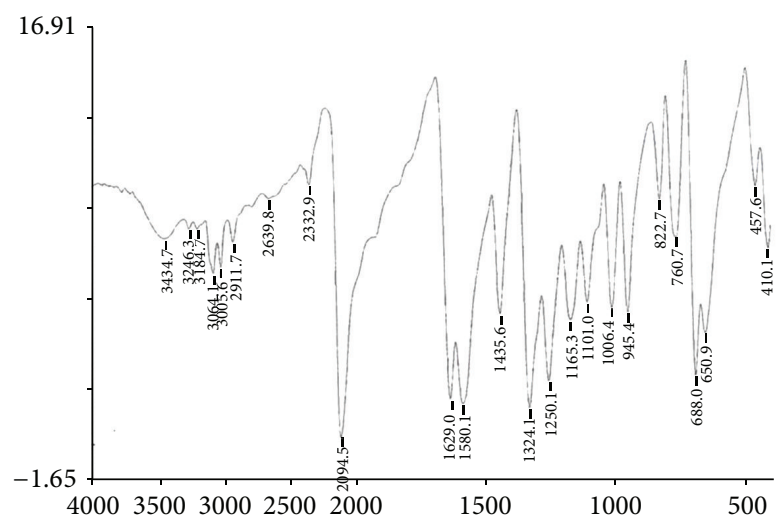

(c)

FIGURE 1: (a) ORTEP drawing (40\% probability ellipsoids) of the $\left[\mathrm{Mn}(\mathrm{Phpyk})_{2}(\mathrm{SCN})_{2}\right]$ complex (primed atoms at $\left.-x, y,-z+1 / 2\right)$. (b) Thermogravimetric analysis (TGA) of the coordination complex $\left[\mathrm{Mn}(\mathrm{Phpyk})_{2}(\mathrm{SCN})_{2}\right]$. (c) FTIR spectroscopic analysis of the coordination complex $\left[\mathrm{Mn}(\mathrm{Phpyk})_{2}(\mathrm{SCN})_{2}\right]$.

TABLE 1: Thermal analyses data of the coordination complex $\left[\mathrm{Mn}(\mathrm{Phpyk})_{2}(\mathrm{SCN})_{2}\right]$.

\begin{tabular}{lcccc}
\hline Complex & Initial temp. of dec. $\left({ }^{\circ} \mathrm{C}\right)$ & Final temp. of dec. $\left({ }^{\circ} \mathrm{C}\right)$ & Calculated weight loss $(\%)$ & Experimental weight loss $(\%)$ \\
\hline$\left[\mathrm{Mn}(\mathrm{Phpyk})_{2}(\mathrm{SCN})_{2}\right]$ & 210 & 540 & 83.8 & 92.8 \\
\hline
\end{tabular}

group of the hemilabile legend, phpyk at around $1640 \mathrm{~cm}^{-1}$ and skeletal vibrations at $\sim 1430$ and $\sim 1580 \mathrm{~cm}^{-1}$ (Figure 1(c)).

3.4. In Vitro Cell Proliferation Study. Selectivity and good antileukemic efficacy are one of the basic requirements of an anticancer agent. In our study, two types of leukemic cell lines (KG-1A and K562) and normal peripheral blood lymphocytes (PBL) were exposed to DOX and MMTC at the concentrations of $0,1,10,25$, and $50 \mu \mathrm{g} \mathrm{mL}^{-1}$ for 24 hours, and cytotoxicity was determined using MTT assay (Figures 2(a) and 2(b)). Results have shown that MMTC up to $25 \mu \mathrm{g} \mathrm{mL}^{-1}$ did not produce any significant $(P<0.05)$ cytotoxic effects in PBL. As the dose increased to $50 \mu \mathrm{g} \mathrm{mL}^{-1}$, cell viability of PBL was decreased significantly by $47.77 \%$ due to MMTC exposure. MMTC exposure was significant $(P<0.05)$ and caused a reduction in cell viability in leukemic cell lines by dose dependent fashion. In KG-1A cell line, the viability was significantly decreased by $58.82 \%$ and $61.38 \%$ at 25 and $50 \mu \mathrm{g} \mathrm{mL}^{-1}$ doses, respectively, whereas in K562 cell line this metal complex was able to reduced cell viability by $56.97 \%$ and $63.31 \%$ at 25 and $50 \mu \mathrm{g} \mathrm{mL}^{-1}$ doses, respectively. Simultaneously, doxorubicin showed potential toxic effects on normal PBL. It decreased the viability of PBL significantly $(P<0.05)$ by $46.93 \%, 72.69 \%$, and $81.08 \%$ at 10 , 25 , and $50 \mu \mathrm{g} \mathrm{mL}^{-1}$ doses, respectively. In leukemic cell lines DOX significantly $(P<0.05)$ decreased cell viability from $10 \mu \mathrm{g} \mathrm{mL}^{-1}$ dose.

From this result, it can be stated that though DOX exerted more potent antileukemic potential, side by side, it showed 


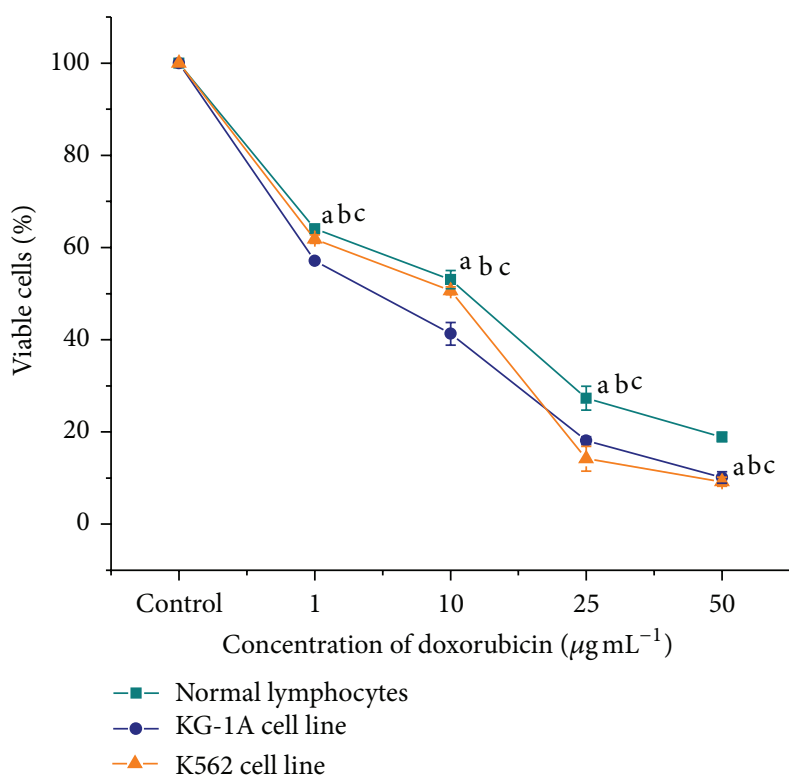

(a)

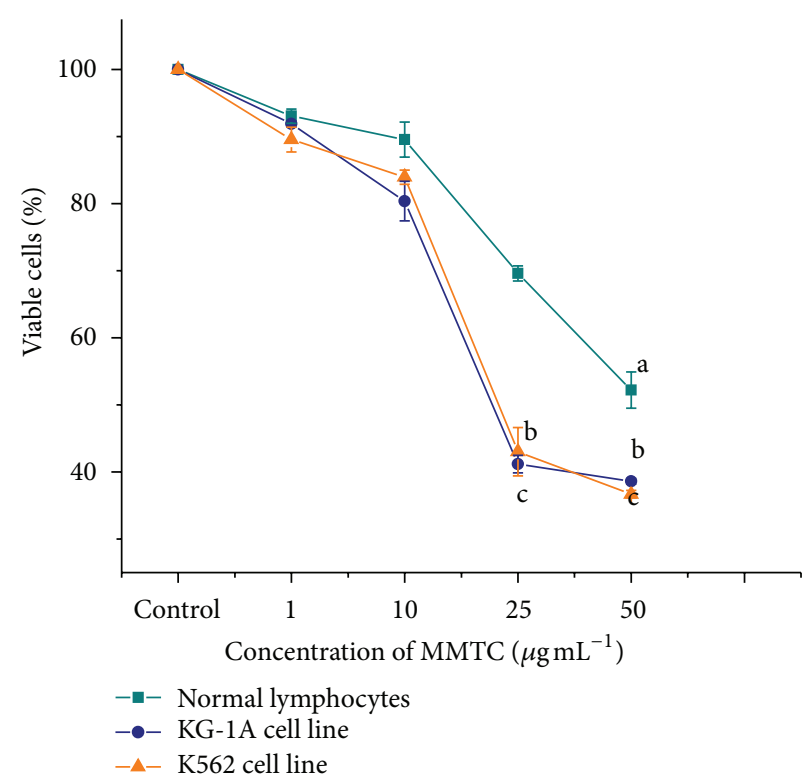

(b)

FIGURE 2: In vitro cell proliferation assay of doxorubicin treated (a) and MMTC treated (b) normal lymphocytes, KG-1A and K562 cell lines. Cells were treated with doxorubicin and MMTC for $24 \mathrm{~h}$ at $37^{\circ} \mathrm{C}$. Cell viability was measured by the MTT method as described in Section 2 . Values are expressed as mean \pm SEM of three experiments; $*$ and \# indicate significant difference $(P<0.05)$ compared to the control group.

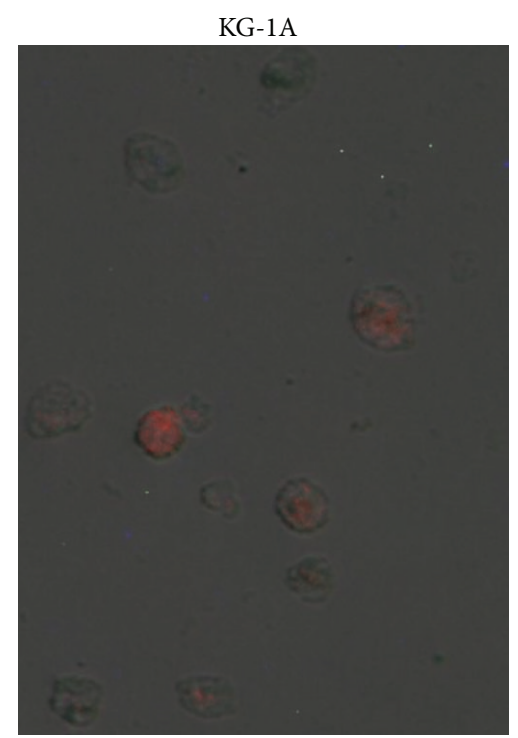

(a)

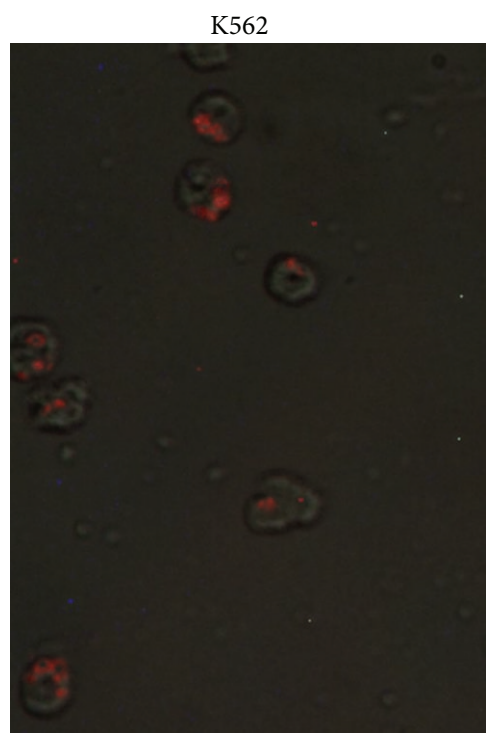

(b)

FIGURE 3: Intracellular uptake of MMTC in KG-1A and K562 cell lines by fluorescence imaging. A required amount of cells was treated with Rhodamine B labeled MMTC for $6 \mathrm{~h}$. Intracellular uptake was examined using fluorescence microscope.

severe toxic effects on PBL. The cytotoxic effects of DOX toward normal cells have already been reported by many researchers $[12,22]$. In our study, manganese (II) containing metal complex showed potent antileukemic effects in both cell lines which is supported by many researchers [23, 24]. On the other hand, MMTC did not produce any significant $(P<0.05)$ toxic effects toward healthy cells up to $25 \mu \mathrm{g} \mathrm{mL}^{-1}$ dose. Collectively, these results demonstrate that this dose can be taken as an effective dose for antileukemic therapy using MMTC. So, further experiments were done using this dose only.

3.5. Intracellular Uptake by Fluorescence Imaging. Metal complexes binding to the plasma membrane and intracellular uptake are probably a necessary condition for their exertion of cytotoxicity. We have shown that MMTC was taken up by 


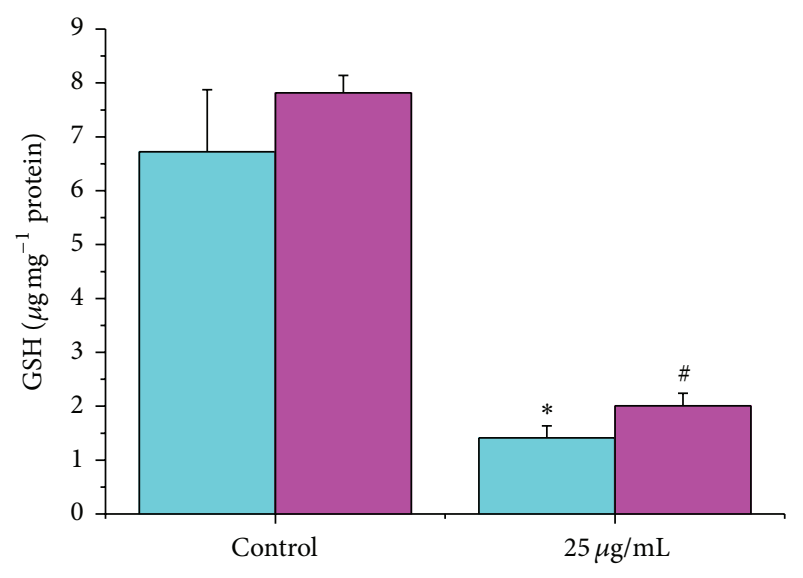

(a)

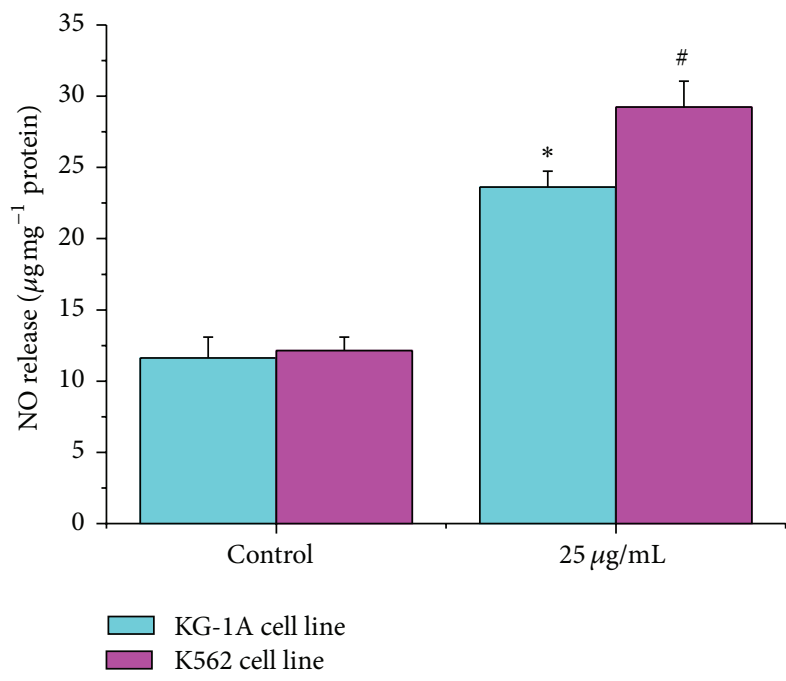

(c)

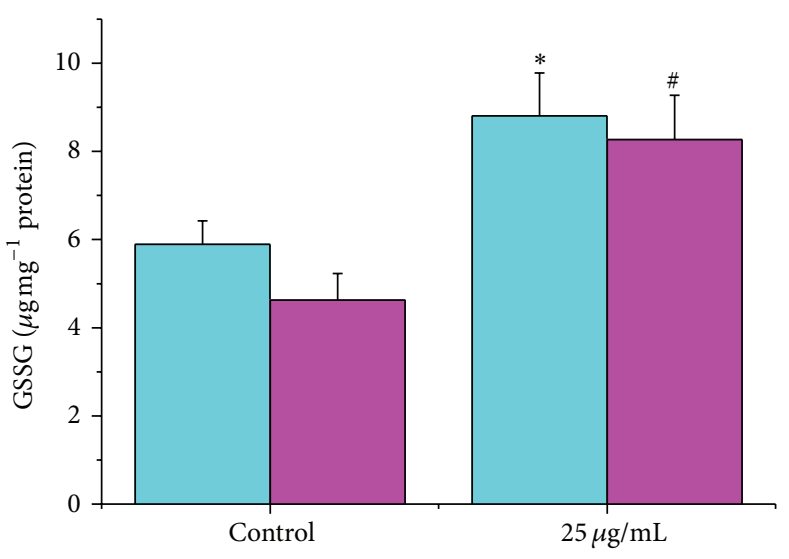

(b)

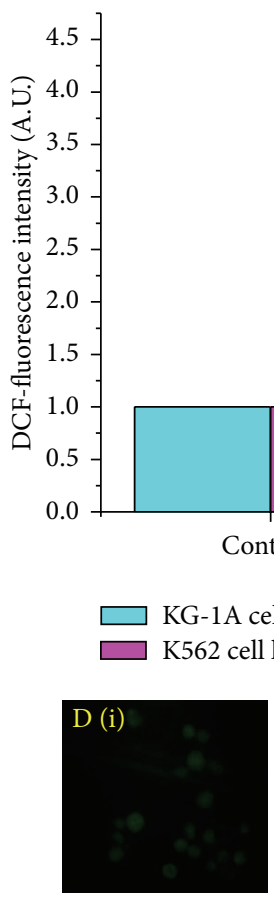

Control $25 \mu \mathrm{g} / \mathrm{mL}$
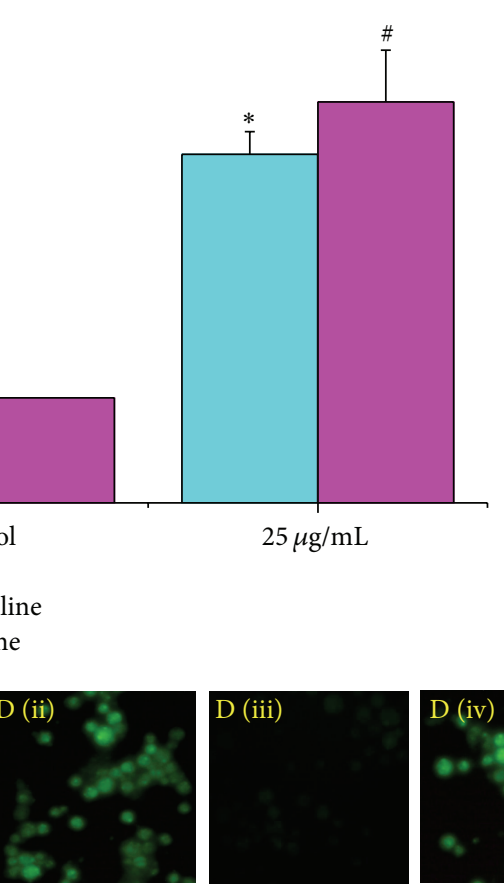

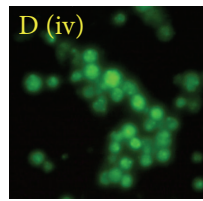

(d)

Figure 4: (a) Intracellular reduced glutathione (GSH) levels of MMTC treated KG-1A and K562 cell lines. The levels of GSH were expressed as $\mu \mathrm{g}$ of GSH mg ${ }^{-1}$ protein. (b) Intracellular oxidized glutathione (GSSG) levels of MMTC treated KG-1A and K562 cell lines. The levels of GSSG were expressed in terms of $\mu \mathrm{g}$ of GSSG mg ${ }^{-1}$ protein. Nitric oxide (NO) release levels of MMTC treated KG-1A and K562 cell lines. (c) The levels of NO were expressed as $\mu \mathrm{mol} \mathrm{mg}{ }^{-1}$ protein. (d) Effects of MMTC on ROS induction in KG-1A and K562 cell lines. Data is represented as the percentage of the ROS level in the control group. Values are expressed as mean \pm SEM of three experiments; $*$ and \# indicate significant difference $(P<0.05)$ compared to the control group. (D (i), D (ii), D (iii), and D (iv)) Qualitative characterization of reactive oxygen species formation by $\mathrm{DCFH}_{2}$-DA staining using fluorescence microscopy. Here, D (i): Control KG-1A cells; D (ii): MMTC treated KG-1A cells; D (iii): Control K562 cells; D (iv): MMTC treated K562 cells.

KG-1A and K562 cell lines in in vitro cultures (Figure 3). From the fluorescence micrographs, it was found that fluorescence labeled MMTC was distributed throughout the cytoplasm, indicating the successful uptake of complex in the cells [12]. The internalization processes of MMTC may be due to phagocytosis, pinocytosis, or endocytosis, have all been well studied and seem to strongly depend on particle form, size and cell type used [25]. Effective cellular uptake of any antileukemic drug is necessary for the exertion of potent anti proliferative effects.

3.6. Cellular Redox Status (GSH and GSSG Levels). Glutathione is an important antioxidant in the cellular system [26]. Many of the anticancer agents trigger the glutathione system. So, to understand the glutathione level, we have measured both the reduced glutathione (GSH) and the oxidized 


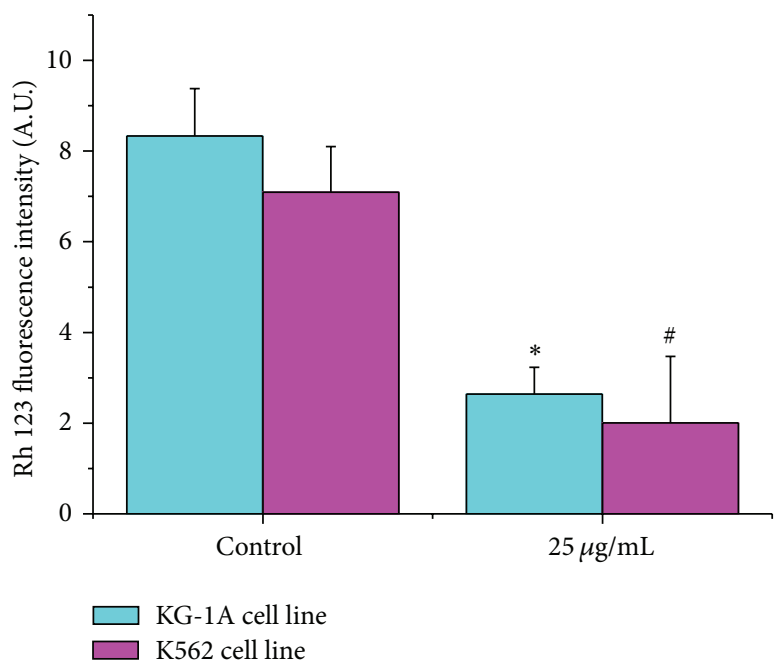

(a)

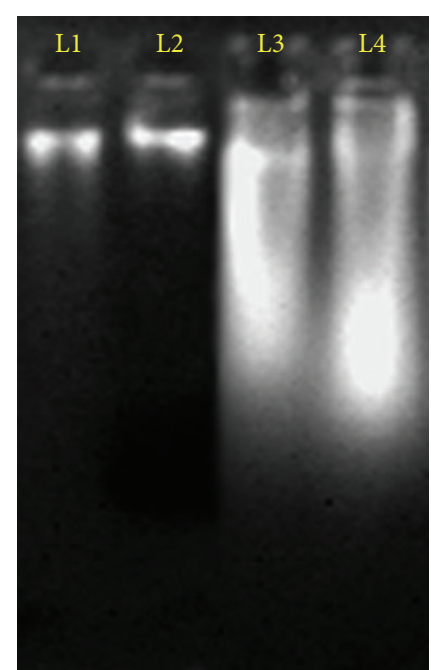

(b)

Figure 5: (a) Measurement of mitochondrial membrane potential (MMP) of MMTC treated KG-1A and K562 cell lines. Data is represented as the percentage of the MMP level in the control group. Values are expressed as mean \pm SEM of three experiments; * and \# indicate significant difference $(P<0.05)$ compared to the control group. (b) DNA fragmentation study by agarose gel electrophoresis. Here, L1: untreated KG-1A cells; L2: untreated K562 cells; L3 and L4: MMTC treated KG-1A and K562 cells, respectively.

glutathione (GSSG). Exposure with MMTC decreased the reduced glutathione (GSH) level in both leukemic cell lines. In KG-1A cell line, GSH level was significantly $(P<0.05)$ decreased by $78.97 \%$, and in the case of K562 cell, lines it was decreased by $74.35 \%$ at $25 \mu \mathrm{g} \mathrm{mL}^{-1}$ dose (Figure 4(a)). The GSSG level was also elevated significantly $(P<0.05)$ in MMTC treated leukemic cells by $49.46 \%$ (in KG-1A cell line), and $78.78 \%$ (in K562 cell line) at the same dose (Figure 4(b)).

Glutathione acts as an important intracellular reductant, and it functions as a direct reactive free radical scavenger. In this study, decreased GSH level may be due to increasing level of lipid oxidation products which may be associated with the less availability of NADPH required for the activity of GR to transform GSSG to GSH due to the increased production of free radicals at a rate that exceeds the ability to regenerate GSH in cells [26]. Thus, it can be understood that this MMTC kills leukemic cells by generating oxidative stress and altering cellular redox homeostasis [8].

3.7. Nitric Oxide Release Level. In a biological system, the free radical NO is an intra- and inter-cellular messenger [27]. Figure 4(c) showed that MMTC exposure significantly increased NO level in leukemic cells at $25 \mu \mathrm{g} \mathrm{mL}^{-1}$ dose. In KG-1A cell line by MMTC was able to elevate NO level by $103.19 \%$, and $140.67 \%$ in K562 cell line.

NO reacts with superoxide to form a more toxic peroxynitrite $\left(\mathrm{ONOO}^{-}\right)$, which has an important microbicidal and tumoricidal function. In our study, the elevated level of NO in leukemic cells may be due to severe oxidative injury which in turn helped in cell killing ability due to MMTC exposure [28].

3.8. Cellular ROS Level. Leukemic cells (KG-1A and K562 cell lines) exposed to MMTC in 24 hours showed increased ROS formation as evidenced by the increased DCF fluorescence intensity. In our study, MMTC exposure significantly $(P<$ 0.05 ) increased ROS generation level by $232 \%$ in KG-1A cell line and by $282 \%$ in K562 cell line at the effective dose (Figure 4(d) and D (i)-D (iv)).

Reactive oxygen species (ROS) are molecules and ions containing unpaired valence shell electrons, and being free radicals they are highly active and show an important role in cell signaling, leading to oxidative cell damage [29]. In the normal cell, glutathione effectively eliminates ROS and thereby maintain cellular normal metabolic behavior. In our study, increased level of ROS in leukemic cells may be due to the increased conversion of GSH to GSSG [26]. This finding indicates that the MMTC kills the leukemic cells by generating ROS level.

\subsection{Alterations of Mitochondrial Membrane Potential (MMP).} One of the possible mechanisms involved in the apoptosis of KG-1A cell line and K562 cell line induced by MMTC was the loss of mitochondrial membrane potential. Mitochondrial membrane potential was determined in terms of Rhodamine 123 fluorescence intensity. In this study, MMTC caused depletion of MMP in both cell lines. In KG-1A cell line, MMP was decreased by $68.27 \%$ and in K562 cell line by $71.75 \%$ (Figure 5(a)).

Loss of MMP and increased DNA fragmentations are the most common targets for apoptosis induced cell death [30]. Alteration of $\Delta \Psi \mathrm{m}$ in MMTC treated leukemic cells may be due to a malfunction in ATP synthesis and maintenance of ATP level that leads to either apoptosis or necrosis [31]. In our study, depleted level of MMP may suggest that MMTC was capable of killing the leukemic cells by induction of apoptosis phenomenon. 
3.10. DNA Fragmentation. DNA fragmentation study in terms of agarose gel electrophoresis revealed that MMTC was able to interact with the DNA of leukemic cells. Qualitative gel documentation image (Figure 5(b)) suggested that a $25 \mu \mathrm{g} \mathrm{mL}^{-1}$ dose of MMTC for $24 \mathrm{~h}$ was capable of fragmenting the DNA strands of KG-1A and K562 cell lines, indicating the involvement of oxidative injury and apoptosis.

The DNA fragmentation is caused by the activation of an endogenous nuclear endonuclease, which selectively and distinctively cleaves the double-stranded nuclear DNA at sites located between nucleosomal units (linker DNA), generating mono- and oligonucleosomal DNA fragments [32]. In our study, elevated level of RNS and ROS may contribute to severe genotoxic effects in leukemic cell lines.

\section{Conclusion}

In this study, we have demonstrated that MMTC exhibited antileukemic activity in AML and CML cells by dosedependent manner, whereas it appeared to be less cytotoxic in human normal lymphocytes up to a certain dose. Involvement of oxidative stress mediated by RNS and ROS, alteration of cellular redox status, loss of mitochondrial membrane potential, and genotoxic effects were observed due to MMTC exposure. Based on these results, it can be concluded that oxidative stress is the possible antileukemic mechanism underlying the etiology of cytotoxicity and apoptosis induced by MMTC. However, further studies are necessary to reduce the cytotoxic effects of MMTC in normal cells and to understand the mode of action of such a complex in leukemic cells.

\section{Conflict of Interests}

The authors declare that there is no conflict of interests.

\section{Acknowledgment}

The authors express gratefulness to the University of Calcutta, Kolkata, and Vidyasagar University, Midnapore, for providing the facilities to execute these studies.

\section{References}

[1] Leukemia, Mosby's Medical, Nursing \& Allied Health Dictionary, Mosby-Year Book, Maryland Heights, Mo, USA, 4th edition, 1994.

[2] S. Faderl, M. Talpaz, Z. Estrov, and H. M. Kantarjian, "Chronic myelogenous leukemia: biology and therapy," Annals of Internal Medicine, vol. 131, no. 3, pp. 207-219, 1999.

[3] B. Rosenberg, L. VanCamp, J. E. Trosko, and V. H. Mansour, "Platinum compounds: a new class of potent antitumour agents," Nature, vol. 222, no. 5191, pp. 385-386, 1969.

[4] S. Rafique, M. Idrees, A. Nasim, H. Akbar, and A. Athar, "Transition metal complexes as potential therapeutic agents," Biotechnology and Molecular Biology Reviews, vol. 5, no. 2, pp. 38-45, 2010.

[5] P. C. A. Bruijnincx and P. J. Sadler, "New trends for metal complexes with anticancer activity," Current Opinion in Chemical Biology, vol. 12, no. 2, pp. 197-206, 2008.
[6] S. Rafique, M. Idrees, A. Nasim, H. Akbar, and A. Athar, "Transition metal complexes as potential therapeutic agents," Biotechnology and Molecular Biology Reviews, vol. 5, no. 2, pp. 38-45, 2010.

[7] A. A. Warra, "Transition metal complexes and their application in drugs and cosmetics-a Review," Journal of Chemical and Pharmaceutical Research, vol. 3, no. 4, pp. 951-958, 2011.

[8] U. Jungwirth, C. R. Kowol, B. K. Keppler, C. G. Hartinger, W. Berger, and P. Heffeter, "Anticancer activity of metal complexes: involvement of redox processes," Antioxidants and Redox Signaling, vol. 15, no. 4, pp. 1085-1127, 2011.

[9] C. G. Dismukes and J. Reedijk, Bioinorganic Catalysis, Marcel Dekker, New York, NY, USA, 1st edition, 1993.

[10] D. D. Perrin, W. L. F. Armarigo, and D. R. Perrin, Purification of Laboratory Chemicals, Pergamon Press, Oxford, UK, 2nd edition, 1980.

[11] T. Ghosh, T. Chattopadhyay, S. Das et al., "Thiocyanate and dicyanamide anion controlled nuclearity in $\mathrm{Mn}, \mathrm{Co}, \mathrm{Ni}, \mathrm{Cu}$, and Zn metal complexes with hemilabile ligand 2-benzoylpyridine," Crystal Growth and Design, vol. 11, no. 7, pp. 3198-3205, 2011.

[12] S. Chattopadhyay, S. P. Chakraborty, D. Laha, R. Bara, P. Pramanik, and S. Roy, "Surface-modified cobalt oxide nanoparticles: new opportunities for anti-cancer drug development," Cancer Nanotechnology, vol. 3, no. 1-6, pp. 13-23, 2012.

[13] L. Hudson and F. C. Hay, Practical Immunology, Blackwell Publishing, Oxford, UK, 3rd edition, 1989.

[14] S. K. Mahapatra, S. P. Chakraborty, S. Das, and S. Roy, "Methanol extract of Ocimum gratissimum protects murine peritoneal macrophages from nicotine toxicity by decreasing free radical generation, lipid and protein damage and enhances antioxidant protection," Oxidative Medicine and Cellular Longevity, vol. 2, no. 4, pp. 222-230, 2009.

[15] S. K. Sahu, S. K. Mallick, S. Santra, T. K. Maiti, S. K. Ghosh, and P. Pramanik, "In vitro evaluation of folic acid modified carboxymethyl chitosan nanoparticles loaded with doxorubicin for targeted delivery," Journal of Materials Science, vol. 21, no. 5, pp. 1587-1597, 2010.

[16] S. K. Dey and S. Roy, "Role of GSH in the amelioration of chromium-induced membrane damage," Toxicological \& Environmental Chemistry, vol. 92, no. 2, pp. 261-269, 2012.

[17] L. U. Ling, K.-B. Tan, H. Lin, and G. N. C. Chiu, "The role of reactive oxygen species and autophagy in safingol-induced cell death," Cell Death and Disease, vol. 2, no. 3, 2011.

[18] N. Zamzami, C. Maisse, D. Métivier, and G. Kroemer, "Measurement of membrane permeability and the permeability transition of mitochondria," Methods in Cell Biology, vol. 80, pp. 327-340, 2007.

[19] S. Kar Mahapatra, S. P. Chakraborty, S. Majumdar, B. G. Bag, and S. Roy, "Eugenol protects nicotine-induced superoxide mediated oxidative damage in murine peritoneal macrophages in vitro," European Journal of Pharmacology, vol. 623, no. 1-3, pp. 132-140, 2009.

[20] Bruker, SMART, SAINT. Software Reference Manual, Bruker AXS, Madison, Wis, USA, 2000.

[21] G. M. Sheldrick, "A short history of SHELX," Acta Crystallographica Section A, vol. 64, no. 1, pp. 112-122, 2007.

[22] A. Dhawan, M. A. Kayani, J. M. Parry, E. Parry, and D. Anderson, "Aneugenic and clastogenic effects of doxorubicin in human lymphocytes," Mutagenesis, vol. 18, no. 6, pp. 487-490, 2003. 
[23] C. L. Chen, X. F. Zhu, M. X. Li, H. M. Guo, and J. Y. Niu, "Antitumor activity of manganese(II) and cobalt(III) complexes of 2-acetylpyridine schiff bases derived from Smethyldithiocarbazate: synthesis, characterization, and crystal structure of the manganese(II) complex of 2-acetylpyridine Smethyldithiocarbazate," Russian Journal of Coordination Chemistry, vol. 37, no. 6, pp. 435-438, 2011.

[24] G. N. Ramesh, Y. Subba Rao, B. Prathima, V. Sravani, and A. Varada Reddy, "Synthesis, characterization and biological activities of manganese (II) complex: molecular modeling of DNA interactions," Der Pharmacia Lettre, vol. 4, no. 4, pp. 12991307, 2012.

[25] E. Besic Gyenge, X. Darphin, A. Wirth et al., "Uptake and fate of surface modified silica nanoparticles in head and neck squamous cell carcinoma," Journal of Nanobiotechnology, vol. 9, p. 32, 2011.

[26] S. Tripathy, S. Das, S. P. Chakraborty, S. K. Sahu, P. Pramanik, and S. Roy, "Synthesis, characterization of chitosantripolyphosphate conjugated chloroquine nanoparticle and its in vivo anti-malarial efficacy against rodent parasite: a dose and duration dependent approach," International Journal of Pharmaceutics, vol. 434, no. 1-2, pp. 292-305, 2012.

[27] S. H. Snyder and D. S. Bredt, "Nitric oxide as a neuronal messenger," Trends in Pharmacological Sciences, vol. 12, no. 4, pp. 125-128, 1991.

[28] H. Ischiropoulos, M. F. Beers, S. T. Ohnishi, D. Fisher, S. E. Garner, and S. R. Thom, "Nitric oxide production and perivascular tyrosine nitration in brain after carbon monoxide poisoning in the rat," Journal of Clinical Investigation, vol. 97, no. 10, pp. 2260-2267, 1996.

[29] K. J. Davies, “An overview of oxidative stress,” IUBMB Life, vol. 50, no. 4-5, pp. 241-244, 2000.

[30] S. K. Sohaebuddin, P. T. Thevenot, D. Baker, J. W. Eaton, and L. Tang, "Nanomaterial cytotoxicity is composition, size, and cell type dependent," Particle and Fibre Toxicology, vol. 7, p. 22, 2010.

[31] C. Adrie, M. Bachelet, M. Vayssier-Taussat et al., "Mitochondrial membrane potential and apoptosis peripheral blood monocytes in severe human sepsis," American Journal of Respiratory and Critical Care Medicine, vol. 164, no. 3, pp. 389-395, 2001.

[32] L. S. Yazan, F. H. Ahmad, O. C. Li, R. A. Rahim, H. A. Hamid, and L. P. Sze, "Betulinic acid was more cytotoxic towards the human breast cancer cell line MDA-MB-231 than the human promyelocytic leukaemia cell line HL-60," Malaysian Journal of Pharmaceutical Sciences, vol. 7, no. 1, pp. 23-37, 2009. 


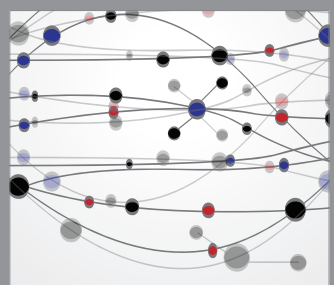

The Scientific World Journal
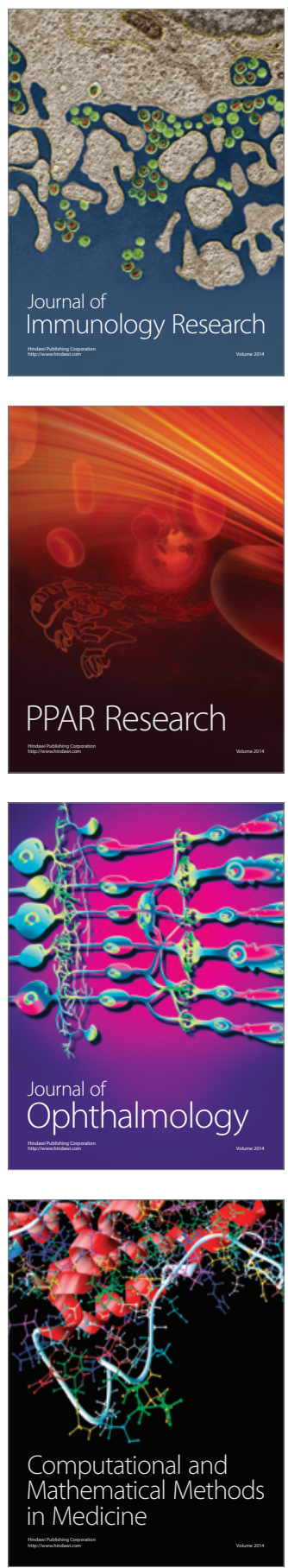

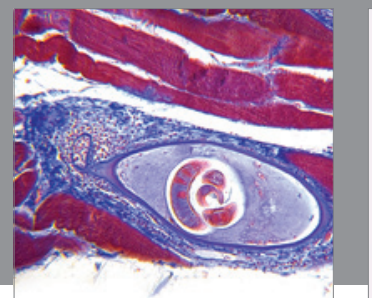

Gastroenterology

Research and Practice
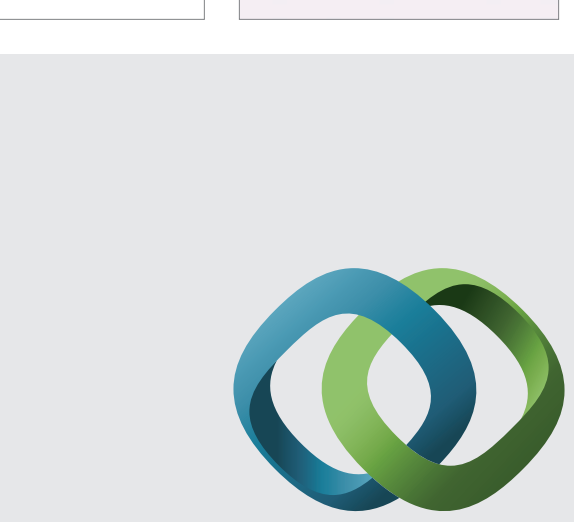

\section{Hindawi}

Submit your manuscripts at

http://www.hindawi.com
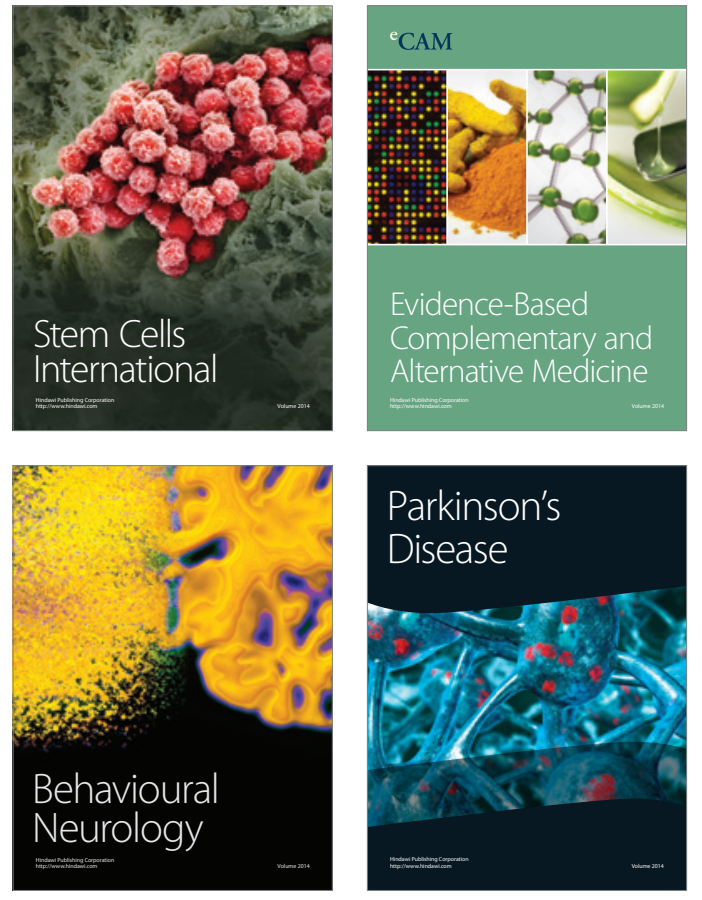
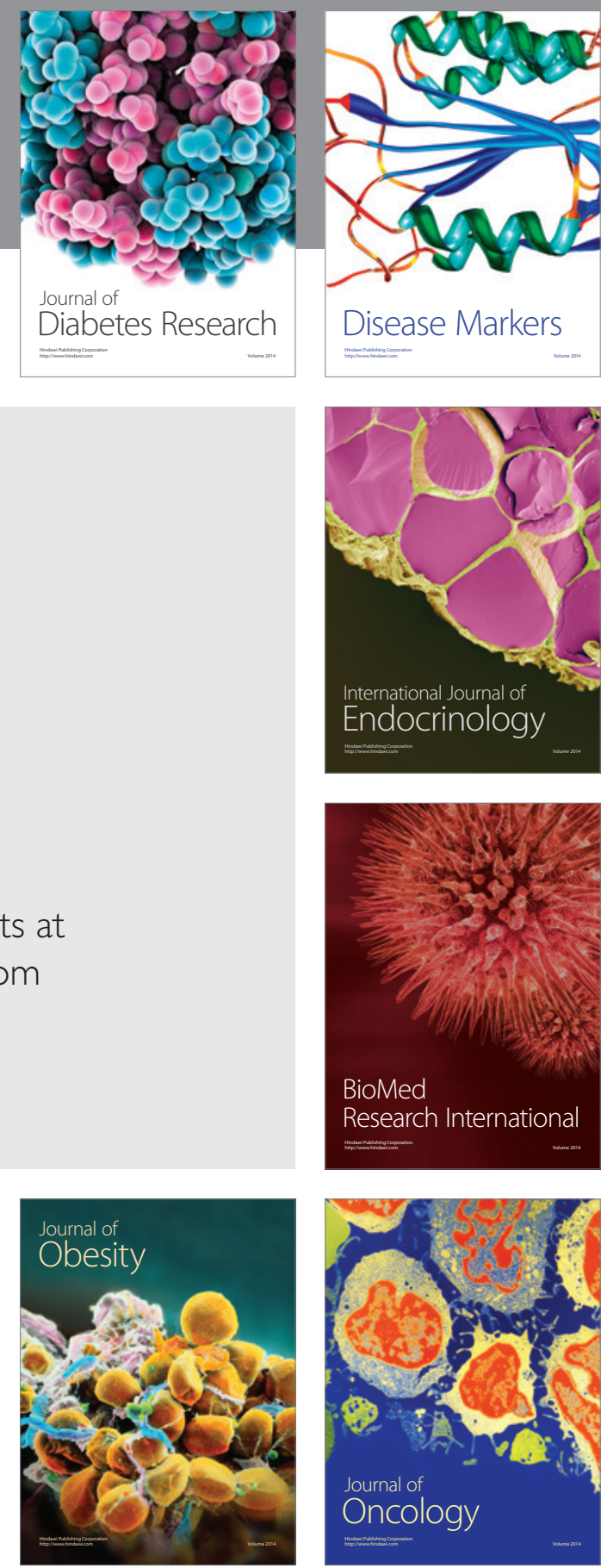

Disease Markers
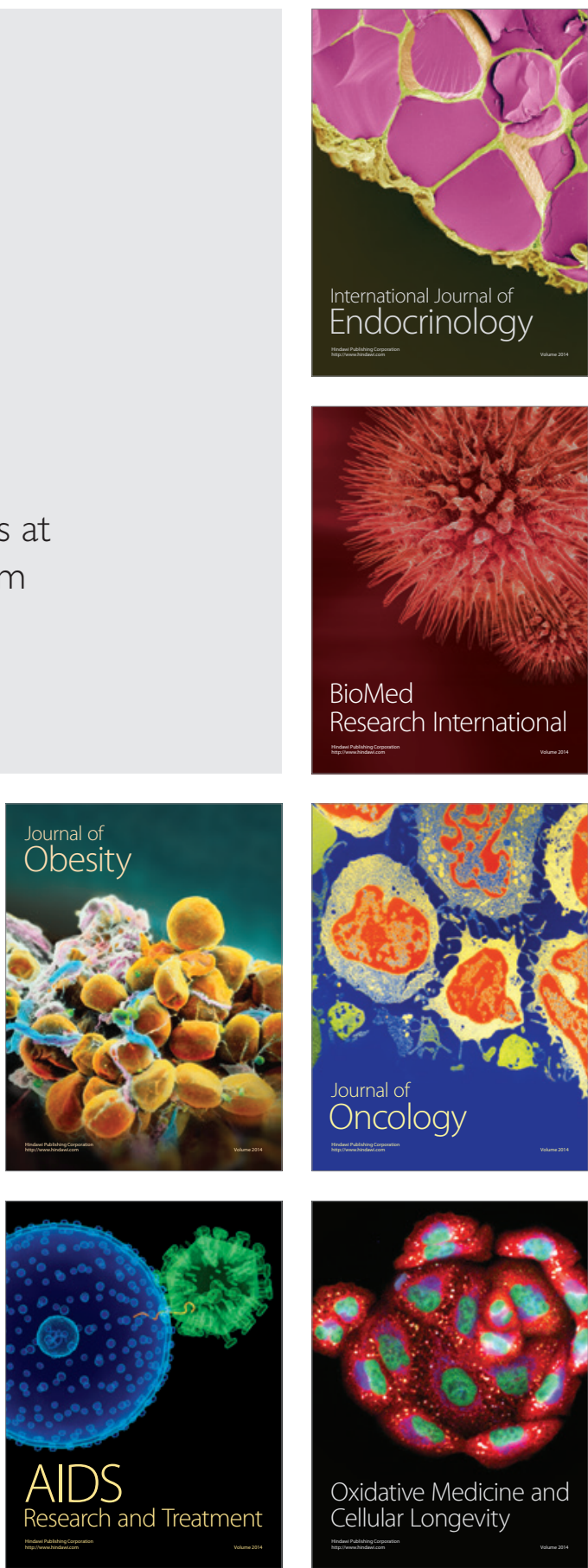